\title{
A histological study on the ventricle of convict cichlid, Amatitlania nigrofasciata (Günther, 1867)
}

\section{Zebra çiklit, Amatitlania nigrofasciata (Günther, 1867) ventriküliü üzerine histolojik bir çalışma}

\author{
Sezgi Arman* • Sema Iş̧isağ Üçüncü \\ Ege University, Faculty of Science, Department of Biology, 35100, Bornova, Izmir \\ *Corresponding author: sezgiarman@gmail.com
}

How to cite this paper:

Arman, S., \& İşisağ Üçüncü, S. (2017 A histological study on the ventricle of convict cichlid, Amatitlania nigrofasciata (Günther, 1867). Ege Journal of Fisheries and Aquatic Sciences, 34(1): 69-73. doi:10.12714/egejfas.2017.34.1.10

\begin{abstract}
The morphological and histological structures of the ventricle of convict cichlid (Amatitlania nigrofasciata) were described light microscopically. The ventricle was pyramidal in shape, and its wall was comprised of epicardium, myocardium, and endocardium. Epicardium and endocardium were thin and had similar histological structure that consisted of simple squamous epithelium and connective tissue. The thicker layer, myocardium, was composed of two layers differentiated easily: the outer part was compactly organized while the inner one was observed as spongy in appearance with large trabeculae oriented between branched bundles of cardiac muscle. The pyramidal shape and myoarchitectural features of the ventricle were evaluated and discussed as being the most important histological parameter of metabolic activity which is depended on myocardial functions.
\end{abstract}

Keywords: Heart, ventricle, Amatitlania nigrofasciata, convict cichlid, histology

Öz: Bu çalışmada zebra çiklit (Amatitlania nigrofasciata) ventrikülünün morfolojik ve histolojik özellikleri ışık mikroskobu ile incelenmiştir. Ventrikül, piramit biçimlidir ve ventrikül duvarı epikardiyum, miyokardiyum ve endokardiyum tabakalarından meydana gelmiştir. Epikardiyum ve endokardiyum tek katlı yassı epitel ile ince bir bağ dokudan oluşmuştur. Daha kalın bir tabaka olan miyokardiyum, kolayca ayırt edilebilen iki tabaka halinde izlenmiştir; dış tabaka, sıkı şekilde organize olmuşken iç tabaka, dallanmış kalp kası demetleri arasında yer alan iri trabekülleri ile süngerimsi görünüme sahiptir. Ventrikülün piramidal biçimi ve kas düzenlenişi metabolik aktivitenin önemli bir parametresi olarak değerlendirilerek tartışımıştır.

Anahtar kelimeler: Kalp, ventrikül, Amatitlania nigrofasciata, zebra çiklit, histoloji

\section{INTRODUCTION}

During the embryogenesis, heart is the first organ that forms and becomes functional in all vertebrates (Yelon, 2001; Glickman and Yelon, 2002). There are significant structural similarities of different vertebrate hearts; three layers of the circulatory system that can be also noticed in heart; epicardium (tunica adventitia), myocardium (tunica media) and endocardium (tunica intima). The outmost layer is pericardium consists of also two distinct layers; fibrous and serous pericardium (University of Leeds, 2003).

Univentricular heart of teleosts, as a prototype of the hearts of higher vertebrates, enable to study the structure, function, physiology and mechanisms (Weinstein and Fishman, 1996; Fishman et al., 1997; Hu et al., 2000). Teleost heart morphology and physiology are well studied by numerous authors (Santer, 1985; Satchell, 1991; Farrell and Jones, 1992; Sánchez-Quintana et al., 1995; Burggren et al., 1997; Simões et al., 2002; Icardo, 2012). It consists of four chambers: the sinus venosus, the atrium, the ventricle and the bulbus arteriosus through the blood flow (Santer, 1985; Stainier and Fishman, 1992; Stainier et al., 1993). The ventricle is the most muscular chamber of the heart that contracts strongly and lead the blood to the ventral aorta via elastic bulbus arteriosus.

Teleost ventricles show some differences in shape; they can be saccular, tubular or pyramidal, and each type has also different myoarchitecture (Sánchez-Quintana et al., 1995). It was reported that mixed ventricular myocardium is well vascularized in its outer compact and inner spongy layers. This type of myocardium of pyramidal ventricle is found in fish with high swimming activity. However, in less active fish that have tubular or saccular ventricles, myocardium is spongy with entirely trabecular muscle (Tota, 1978; Santer and Walker, 1980; Santer et al., 1983; Santer, 1985; Simões et al., 2002). 
Convict cichlid is a freshwater teleost natively diversed in the streams and rivers of Central America, and a very popular aquarium fish (Mousavi-Sabet and Eagderi, 2016). It is also a frequently used model for fish behavior studies (Nelson et al., 2013; Wisenden et al., 2015). The current study is aimed to describe histological features of the ventricle of $A$. nigrofasciata.

\section{MATERIALS AND METHODS}

Ten specimens of $A$. nigrofasciata were obtained commercially and maintained for two weeks in well aerated and filtered aquaria $(40 \mathrm{~L})$ at $26 \pm 2{ }^{\circ} \mathrm{C}$. Photoperiod was $14-\mathrm{h}$ light/10-h dark. They were fed frozen Artemia sp. (Ocean Nutrition $^{\mathrm{TM}}$ ) twice a day.

The specimens were euthanatized with overdose of MS222, the hearts were removed and fixed in Bouin's fluid for 24$\mathrm{h}$ at $4{ }^{\circ} \mathrm{C}$ and routine histological procedures were followed. They were rinsed in distilled water, dehydrated in ethanol, treated with xylene and embedded in paraffin (Presnel et al., 1997). $5 \mu \mathrm{m}$-thick serial sections were stained with Mayer's hematoxylin-eosin ( $\mathrm{H}-\mathrm{E})$. Slides were investigated by light microscopy and photographed by using Euromex HDIl camera attached to Euromex stereomicroscope and Zeiss Axio Scope. A1 equipped with Zeiss AxioCam ERc5s.

\section{RESULTS}

The largest part of the heart of $A$. nigrofasciata was ventricle, the atrium had a thin, muscular wall and atrial lumen composed of loose meshwork of trabeculae; and the bulbus arteriosus had a thick wall consisting of connective tissue fibers (Figure 1).

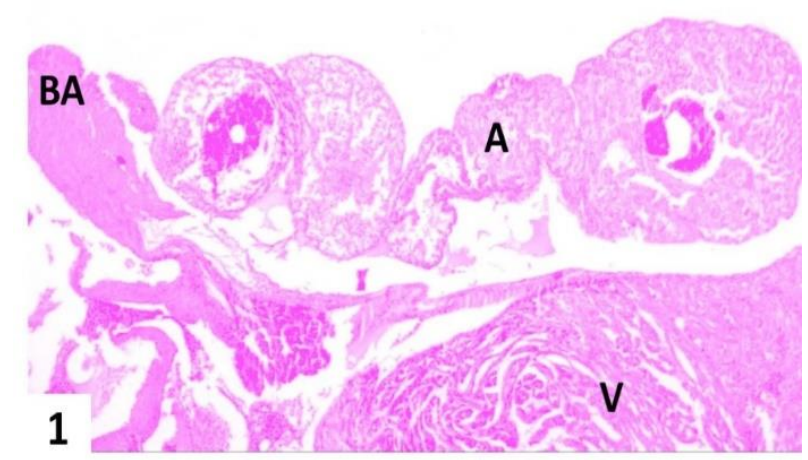

Figure 1. Frontal section of the heart of $A$. nigrofasciata showing the chambers of the atrium $(A)$, the ventricle $(V)$ and the bulbus arteriosus (BA) (original magnification $\mathrm{x} 4$ )

Three distinct layers of pyramidal ventricle (Figure 2) were observed as epicardium, myocardium and endocardium. While epicardium (visceral serous pericardium) was clearly observed, the fibrous pericardium and the pericardial cavity could not be noticed. Epicardium, a thin layer that was consist of flattened epithelial cells (mesothelium) and connective tissue (Figure 3).
2

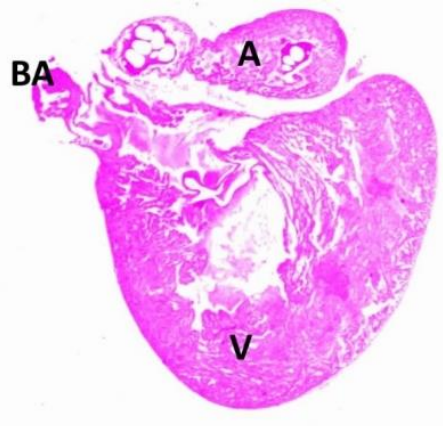

Figure 2. Frontal section of the pyramidal ventricle $(V)$, the atrium $(A)$ and the bulbus arteriosus (BA) (original magnification $\mathrm{x} 2$ )

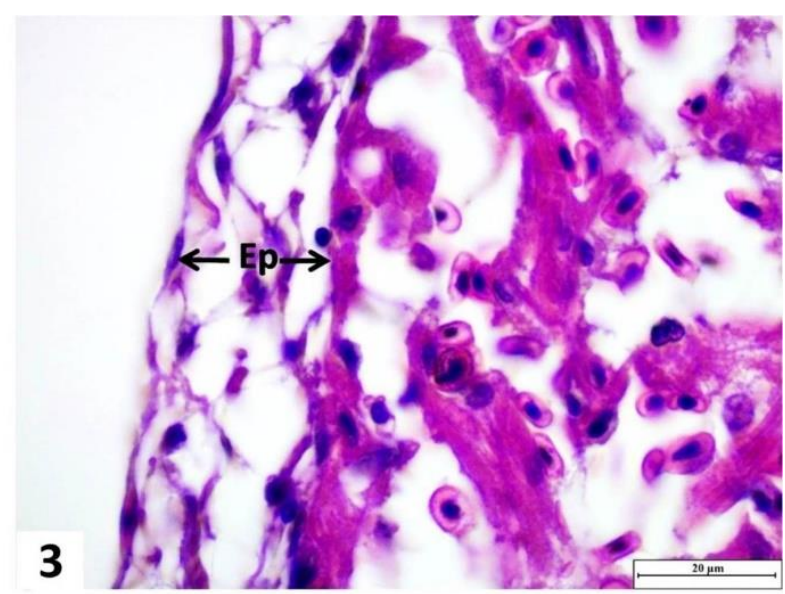

Figure 3. Epicardium (Ep) that is composed of mesothelium and connective tissue

Myocardium was consisted of outer, compact myocardium (compacta) and inner spongy myocardium (spongiosa). In the spongy myocardium, some large trabeculae were noted (Figure 4).

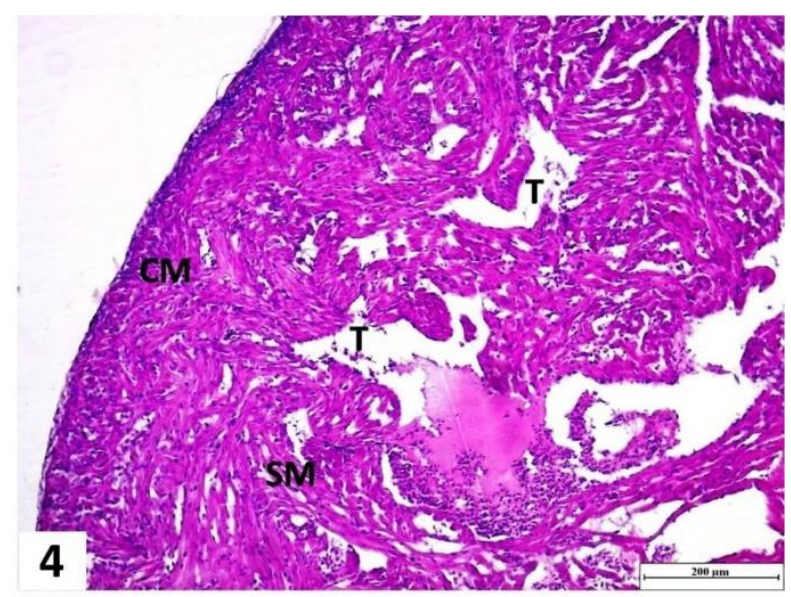

Figure 4. Outer compact myocardium (CM) and inner spongy myocardium (SM) with large trabeculae $(\mathrm{T})$ 
Ellipsoid, centrally located nuclei surrounded by widened perinuclear spaces were observed (Figure 5). Striated appearance of the circular muscle cells were distinguished locally (Figure 6). Cardiac muscle cells as branched fibers were easily noticed, however intercalated discs were partly seen (Figure 7).

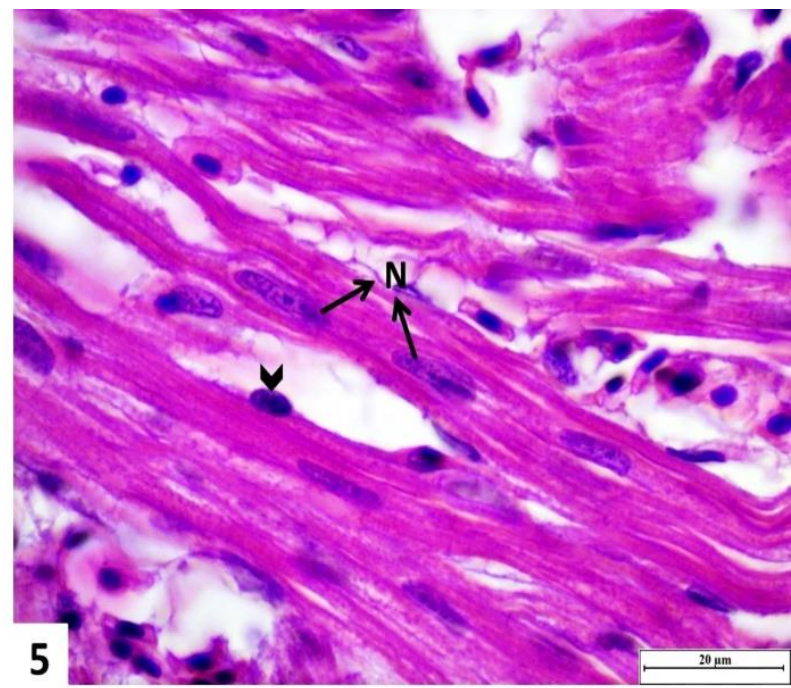

Figure 5. Centrally positioned nuclei (N) of cardiac muscle cells and epithelial cell (arrowhead)

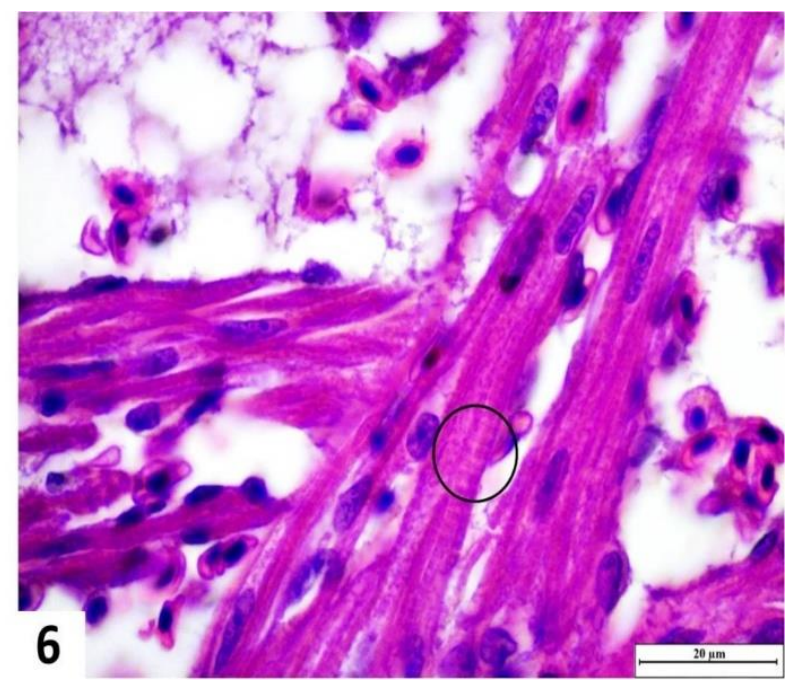

Figure 6. Striated appearance (encircled) of the cardiac muscle fibers

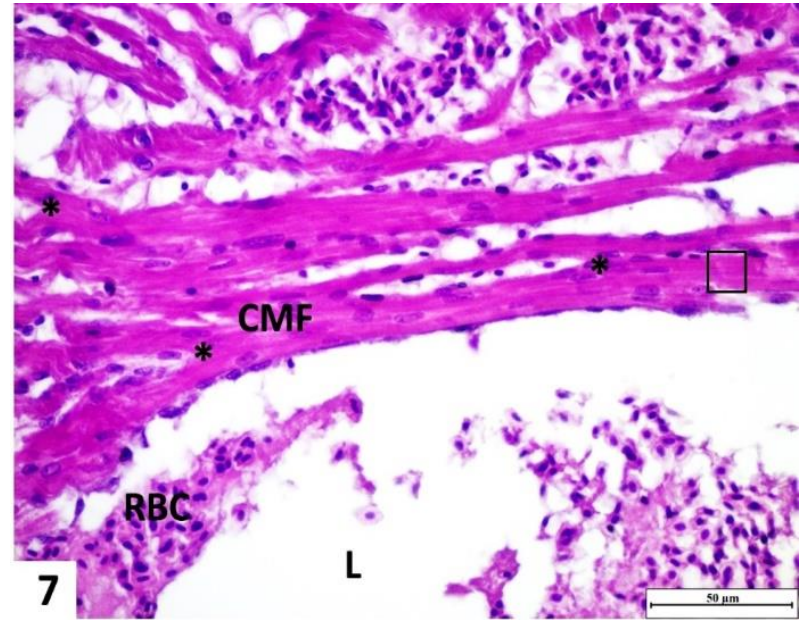

Figure 7. Branched $\left({ }^{*}\right)$ cardiac muscle fibers (CMF) with slightly seen intercalated disc (square), red blood cells (RBC) in the ventricular lumen $(\mathrm{L})$

Endocardium was very thin and composed of simple squamous epithelium (endothelium) and connective tissue (Figure 8).

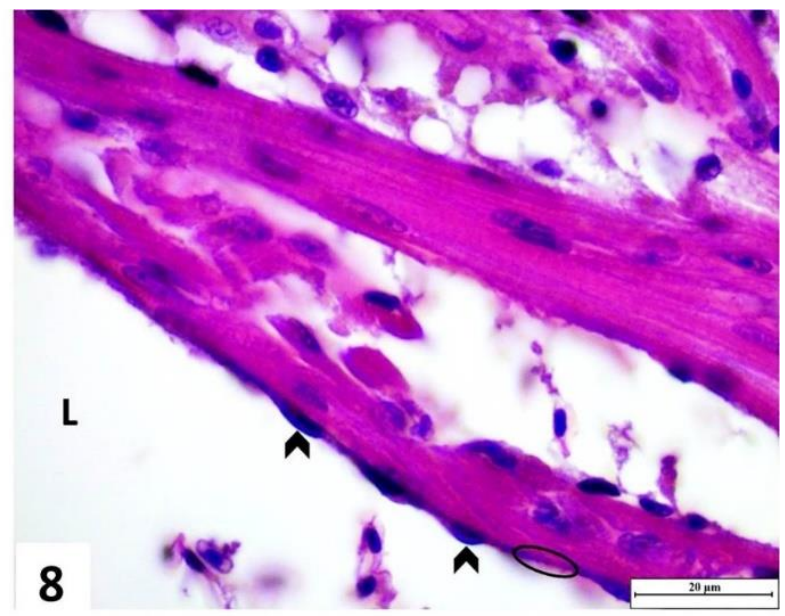

Figure 8. Ventricular lumen (L), simple squamous epithelium (arrowhead) and connective tissue (ellipse) of the endocardium

Atrioventricular and ventriculobulbar valves were observed clearly as of connective tissue flaps covered by endothelium (Figure 9 and 10). 


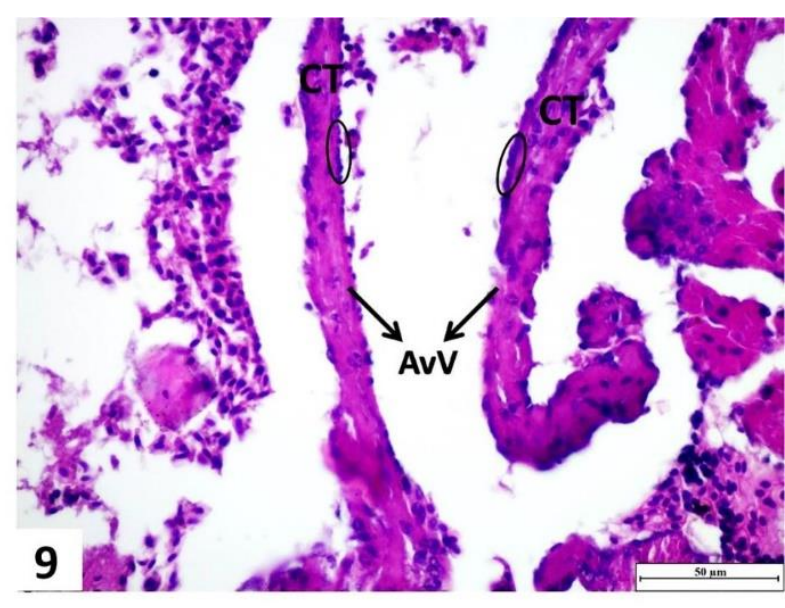

Figure 9. Atrioventricular valve (AvV) consisting of connective tissue (CT) and covered by endocardium (ellipse)

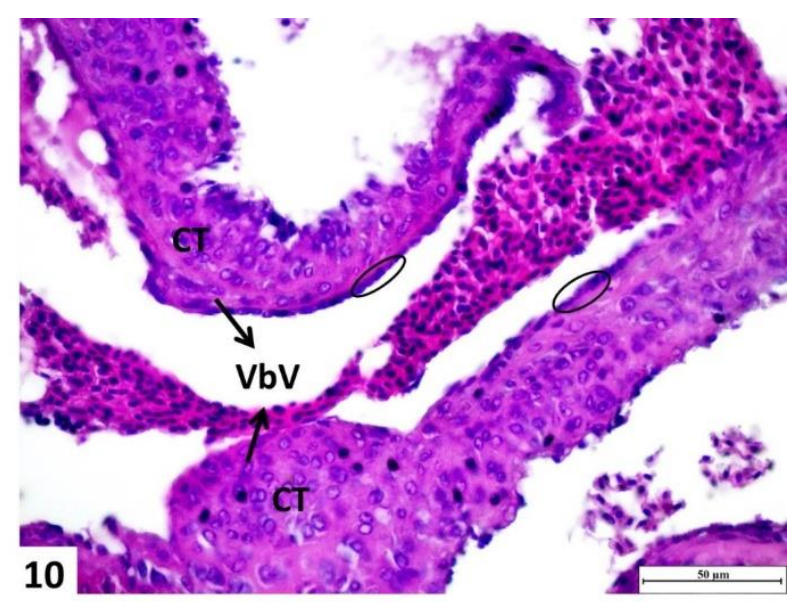

Figure 10. Ventriculobulbar valve ( $\mathrm{VbV})$ consisting of connective tissue (CT) and covered by endocardium (ellipse)

\section{DISCUSSION}

As being the first organ that forms and functions in all vertebrate embryos (Glickman and Yelon, 2002), the anatomy, structure and functions of heart had been well studied; and significant similarities were also well defined histologically in warm and cold-blooded vertebrates. In accordance with

\section{REFERENCES}

Burggren, W.W., Farrell, A.P. \& Lillywhite, H. (1997). Vertebrate cardiovascular systems. Handbook of Comparative Physiology, 215-308. doi: 10.1002/cphy.cp130104

Eliška, O. (2006). Purkinje fibers of the heart conduction system. Casopis Lékařu Českých, 145(4): 329-335.

Eralp, I., Lie-Venema, H., Bax, N.A., Wijfels, M.C., Van Der Laarse, A., DeRuiter, M.C., Bogers, A.J.J.C., Van Der Akker, N.M.S., Gourdie, R.G., Schalij, M.J., Poelmann, R. E. \& Gittenberger-De Groot, A.C. (2006). Epicardium-derived cells are important for correct development of the previous reports (Pérez-Pomares et al., 2009), the organization and histological structures of the heart wall of $A$. nigrofasciata was constructed in three-layers which are exhibited common features. Lacking of Purkinje fibers in lower vertebrates is also a common structural organization (Eliška, 2006; Eralp et al., 2006; Quentin and Moore, 2008); these fibers were not observed in the heart of $A$. nigrofasciata.

External ventricular shape and architectural arrangement show a great variability in different fish. Depending on their shapes, the ventricle can be differentiated as pyramidal, tubular and saccular (Santer, 1985; Sánchez-Quintana et al., 1995; Simões et al., 2002). The pyramidal ventricles were reported in the members of Salmonidae and Scombridae (Farrell and Jones, 1992; Icardo, 2012); also in Pagellus centrodontus (Sánchez-Quintana et al., 1995), Piaractus mesopotamicus and Colossoma macropomum (Simões et al., 2002). The ventricles of Merluccius merluccius was tubular (SánchezQuintana et al., 1995); while Lophius piscatorius (SánchezQuintana et al., 1995) and Clarias gariepinus (Simões et al., 2002) had saccular ones.

Another classification of ventricles could also be done according to presence and relative thickness of compact layer, and the extension of myocardial vascularization (Tota, 1983; Tota, 1989; Tota and Garofalo, 2012; Icardo, 2012).

Although some incompatibilities between the shapes and structures of ventricles were noted, Icardo (2012) was offered a consensus: both of two parameters; the external shape (Santer, 1985) or muscular structure and vascularization of the ventricular wall (Tota, 1983) are suitable for classification.

Ventricular shape and myoarchitecture are naturally correlated with the lifestyle and metabolic activities of fish species. While fast-swimming fish have pyramidal ventricle which has mixed type myocardium that consists of compacta and spongious layers; sedentary or less active fish show tubular or saccular ventricles that present entirely trabeculated myocardium. However, Simões et al. (2002) reported that a freshwater teleost Clarias gariepinus that mostly inhabit shallow, running water, has a saccular shaped ventricle consisted of mixed type myocardium.

A. nigrofasciata is an attractive species that prefers fast moving streams and rivers, and has a pyramidal ventricle constructed with mixed type of myocardium.

Purkinje fibers in the avian heart. The Anatomical Record Part A: Discoveries in Molecular, Cellular, and Evolutionary Biology, 288(12): 1272-1280. doi: 10.1002/ar.a.20398

Farrell, A.P. \& Jones, D.R. (1992). 1 The Heart. Fish physiology, 12: 1-88. doi: 10.1016/S1546-5098(08)60331-3

Fishman, M.S., Stainier, D.Y., Breitbart, R.E. \& Westerfield, M. (1997). Zebrafish: Genetic and embryological methods in a transparent vertebrate embryo. Methods in Cell Biology, 52: 67-82.

doi: 10.1016/S0091-679X(08)60374-X 
Glickman, N.S. \& Yelon, D. (2002). Cardiac development in zebrafish: coordination of form and function. Seminars in Cell \& Developmental Biology, 13: 507-513. doi: 10.1016/S1084952102001040

Hu, N., Sedmera, D., Yost, H.J. \& Clark, E.B. (2000). Structure and function of the developing zebrafish heart. The Anatomical Record, 260:148-157. doi: 10.1002/1097-0185(20001001)260:2<148::AID-AR50>3.0.CO;2-X

Icardo, J.M. (2012). The Teleost Heart: Morphological Approach. In D. Sedmera and T. Wang (Eds.), Ontogeny and Phylogeny of the Vertebrate Heart (pp 35-53). New York: Springer. doi: 10.1007/978-1-4614-3387-3_2

Mousavi-Sabet, H. \& Eagderi, S. (2016). First record of the convict cichlid, Amatitlania nigrofasciata (Günther, 1867)(Teleostei: Cichlidae) from the Namak Lake basin, Iran. Iranian Journal of Ichthyology, 3(1): 25-30. doi: 10.7508/iji.2016.01.003

Nelson, A.B., Alemadi, S.D. \& Wisenden, B.D. (2013). Learned recognition of novel predator odour by convict cichlid embryos. Behavioral Ecology and Sociobiology, 67(8): 1269-1273. doi: 10.1007/s00265-013-1554-1

Pérez-Pomares, J.M., Gonzáles-Rosa, J.M. \& Muñoz-Chápuli, R. (2009) Building the vertebrate heart- an evolutionary approach to cardiac development. The International Journal of Developmental Biology, 53: 1427-1443. doi: 10.1387/ijdb.072409jp

Presnell, J.K., Schreibman, M.P. \& Humason, G.L. (1997). Humason's anima tissue techniques. Johns Hopkins University Press.

Quentin, B. \& Moore, R. (2008). Biology of fishes. UK: Taylor \& Francis Group.

Sánchez-Quintana, D., Garcia-Martinez, V., Climent, V. \& Hurle, J.M. (1995) Morphological anlysis of the fish heart ventricle: myocardial and connective tissue architecture in teleost species. Annals of Anatomy, 177: 267-274. doi: 10.1016/S0940-9602(11)80198-6

Santer, R.M. (1985). Morphology and innervation of the fish heart. Advances in Anatomy, Embryology and Cell Biology, 89: 1-102.

Santer, R.M. \& Walker, M.G. (1980). Morphological studies on the ventricle of teleost and elasmobranch heart. Journal of Zoology, 190: 259-272. doi: 10.1111/j.1469-7998.1980.tb07771.x

Santer, R.M., Walker, M.G., Emerson, L. \& Witthames, P.R. (1983). On the morphology of the heart ventricle in marine teleost fish (Teleostei). Comparative Biochemistry and Physiology, 76A: 453-457. doi:10.1016/0300-9629(83)90445-0

Satchell, G.H. (1991). Physiology and form of fish circulation. Cambridge: Cambridge University.
Simões, K., Vicentini, C.A., Orsi, A.M. \& Cruz, C. (2002). Myoarchitecture and vasculature of the heart ventricle in some freshwater teleosts. Journal of Anatomy, 200: 467-475. doi: 10.1046/j.1469-7580.2002.00023.x

Stainier, D.Y., Lee R.K. \& Fishman, M.C. (1993). Cardiovascular development in the zebrafish I. Myocardial fate map and heart tube formation. Development, 119: 31-40.

Stainier, D.Y.R. \& Fishman, M.C. (1992). Patterning the zebrafish heart tube: acquisition of anteroposterior polarity. Developmental Biology, 153: 91101. doi: 10.1016/0012-1606(92)90094-W

Tota, B. (1978). Functional cardiac morphology and biochemistry in Atlantic bluefin tuna. In: G.D. Sharp, A.E. Dizon (Eds.), The Physiological Ecology of Tunas (pp 89-112). New York: Academic Press. doi: 10.1016/0012-1606(92)90094-W

Tota, B. (1983). Vascular and metabolic zonation in the ventricular myocardium of mammals and fishes. Comparative Biochemistry and Physiology, 76 : 423-437. doi: 10.1016/0300-9629(83)90442-5

Tota, B. (1989). Myoarchitecture and vascularisation of the elasmobranch heart ventricle. Journal of Experimental Zoology, 252(S2): 122-135. doi: 10.1002/jez.1402520413

Tota, B. \& Garofalo, F. (2012). Fish heart growth and function: from gross morphology to cell signalling and back. In D. Sedmera and T. Wang (Eds.), Ontogeny and phylogeny of the vertebrate heart. New York: Springer. doi: 10.1007/978-1-4614-3387-3_3

University of Leeds (2003). The Histology Guide, Circulatory System. Retrieved February 12, 2016 from http://www.histology.leeds.ac.uk/circulatory/heart.php.

Weinstein, B.M. \& Fishman, M.C. (1996). Cardiovascular morphogenesis in zebrafish. Cardiovascular Research, 31: E17-E24. doi: 10.1016/S0008-6363(95)00139-5

Wisenden, B.D., Stumbo, A.D., Self, P.A., Snekser, J.L., McEwen, D.C. Wisenden, P.A., Keenleyside, M.H.A., Itzkowitz, M. \& Brisch, E. (2015). Co-evolution of offspring antipredator competence and parental brood defense in convict cichlids. Hydrobiologia, 748(1): 259-272. doi: 10.1007/s10750-014-1917-2

Yelon, D. (2001). Cardiac patterning and morphogenesis in zebrafish. Developmental Dynamics, 222(4): 552-563. doi: 10.1002/dvdy.1212 